\title{
Developing the metacognitive skill of noticing the gap through self-transcribing: The case of students enrolled in an ELT education program in Chile
}

\section{El desarrollo de la habilidad metacognitiva de tener conciencia del error a través de la auto- transcripción: El caso de estudiantes inscritos en un programa de Pedagogía en Inglés en Chile}

Millaray Salas Valdebenito ${ }^{1}$

Citation / Para citar este artículo: Salas, M. (2015). Developing the metacognitive skill of noticing the gap through self-transcribing: The case of students enrolled in an ELT education program in Chile. Colomb. Appl. Linguist. J., 17(2), pp. 260-275.

Received: 15-Oct-2013 / Accepted: 4-Jun-2015

DOI: http://dx.doi.org/10.14483/udistrital.jour.calj.2015.2.a06

\begin{abstract}
This paper reports the preliminary results of the first phase of an ongoing educational intervention conducted with students enrolled in an ELT education program at PUCV. As an EFL teacher with fossilized errors cannot be an effective language model for students, the study set out to explore the feasibility and effectiveness of a recording and self-transcription task (Lynch, 2001, 2007; Mennim, 2003, 2012) as a route to noticing the gap and defossilization. Students (N=20) transcribed the oral texts they produced during the speaking section of the diagnostic test for English 5. The tasks were: (1) transcribing three minutes of their speaking time, (2) highlighting all the errors they identified in their own speech (3) coding them (e.g. grammatical, lexical, phonological) and (4) sending the annotated transcript to the instructor by email. Drawing on the theory of questionnaire design and processing (Dörnyei, 2003), a survey was designed and posted online (GoogleForm) and emailed to the students. The questionnaire asked students to evaluate the perceived benefits of a self-transcription task. The study data consist of the annotated transcripts and the questionnaire responses. The results of this study were much less positive than what has been reported in the literature (Boettinger, Park, \& Timmis 2010; Burns \& Joyce, 1997; Lynch, 2001, 2007; Mennim, 2003, 2012; Stillwell et al., 2010; Thornbury \& Slade, 2006; Willis \& Willis, 1996): students only noticed 25\% of their errors in a transcript of three minutes' talk. As such, an attempt is made to see why this might have been the case. Some pedagogical implications of this approach in the Chilean context are discussed.
\end{abstract}

Keywords: ELT education, fossilization, noticing the gap, self-transcribing

\section{Resumen}

En este trabajo se reportan los resultados de la primera fase de una intervención pedagógica realizada con estudiantes matriculados en un programa de Pedagogía en Inglés en la PUCV. El estudio se propuso explorar la viabilidad y efectividad de la metodología de grabación y transcripción Lynch, 2001, 2007; Mennim, 2003, 2012) como un medio hacia la conciencia del

1 Pontificia Universidad Católica de Valparaíso, Valparaiso, Chile. millysalas@gmail.com 
error y la desfosilización, ya que un profesor de inglés con errores fosilizados no puede ser un modelo lingüístico adecuado para sus estudiantes. Los estudiantes $(\mathrm{N}=20)$ transcribieron los textos orales que ellos mismos produjeron durante la sección de producción oral de la prueba de diagnóstico de la asignatura de Inglés 5 . Las tareas asignadas consistieron en: (1) transcribir tres minutos del tiempo total de habla, (2) destacar todos los errores que ellos identificaron en su propio desempeño oral, (3) codificarlos (e.g. gramaticales, léxicos, fonológicos) y (4) enviar la transcripción anotada a la profesora por correo electrónico. Basándonos en la teoría de diseño y procesamiento de cuestionarios (Dörnyei, 2003), se diseñó una encuesta que se envió por Internet (GoogleForm) a los participantes. La encuesta buscaba identificar las percepciones de los estudiantes sobre la metodología de auto-transcripción, en especial sus potenciales beneficios. Los datos del estudio consisten en las transcripciones anotadas y las respuestas al cuestionario. Los resultados de la investigación fueron mucho menos positivos que lo que reporta la literatura especializada (Boettinger, Park, \& Timmis 2010; Burns \& Joyce, 1997; Lynch, 2001, 2007; Mennim, 2003, 2012; Stillwell et al., 2010; Thornbury \& Slade, 2006; Willis \& Willis, 1996): los estudiantes solo fueron capaces de notar un $25 \%$ de los errores en una trascripción de tres minutos de su producción oral. Por ello, se analizan las posibles causas y se discuten algunas implicancias pedagógicas de la implementación de esta metodología en el contexto chileno.

Palabras clave: Pedagogía en inglés, fosilización, conciencia del error, auto-transcripción

\section{Introduction}

The average Chilean has a low level of proficiency in English, according to recent sources ${ }^{1,}$ which estimate that only $2 \%$ have a "good" command of the language (See note 1). As a result, the government has recently attempted to address the problem by allocating more funds to initial English Language Teacher (ELT) education. Thus, the state currently funds six-month stays in Englishspeaking countries for a number of trainee teachers and provides scholarships for applicants to ELT courses with high scores in the Chilean University Selection Test (known as PSU). These policies have the potential to have a positive impact, but will not raise the quality of future English teachers without being complemented by other measures. According to the extensive empirical evidence that shows the process of acquiring a second language is very complex, achieving maximum command depends on a combination of cognitive, sociocultural, and individual factors, including the type of instruction employed (Ellis, 1997; Gass \& Selinker, 2008; Lightbown \& Spada, 2006; Mitchell \& Myles, 2004). Indeed, some studies have shown that a stay in an English speaking country does not guarantee improvements in students' grammatical accuracy (DeKeyser, 2007), one of the three dimensions along with fluency and complexity- involved in mastering a foreign language (Larsen-Freeman, 2009).
A teacher of English as a second language (ESL) should be a good language model for his/ her students in terms of grammar and lexicon, phonological and pragmatic aspects, etc. Most ELT education students in Chile are non-native speakers (NNSs) of English, which is not necessarily a disadvantage (Llurda, 2005). However, some aspects of their interlanguage - the language produced by non-native speakers - will present deviations from the native speaker (NS) norms of English (Selinker, 1972). There is ample empirical evidence (Han $\mathcal{E}$ Odlin, 2006) that in most interlanguages there is a cessation of learning, known as fossilization (Selinker, 1972), which results in the learners' interlanguage reaching a plateau and failing to progress any further. A teacher with fossilized errors cannot be an effective language model for students.

Fossilisation can be contextualised in terms of the Output Hypothesis proposed by (Swain 1985, 1993; Swain \& Lapkin, 1995), which suggests that the output, i.e. the learner's oral production in the target language, plays a fundamental role in the development of oral competence. In the Output Hypothesis, a central notion is "noticing the gap." According to Swain (1993), the experience of being pushed to produce oral discourse can trigger in the L2 learner a cognitive process that will lead to "noticing the gap" between the learner's own spoken production and that of more experienced speakers and native speakers of the target language. Swain 
(1993) argues that this metalinguistic awareness of gaps in their own linguistic knowledge allows L2 learners to identify their own mistakes, reassess their assumptions about the target language, and edit their statements.

In short, the development of this metalinguistic awareness can increase learner autonomy, facilitate the progress of L2 learning, and prevent fossilization: only learners who notice the gap will be able to selfcorrect and destabilize fossilized errors. The latter is of crucial importance, because once ELT students complete their initial teacher education program they will no longer receive corrective feedback from their teachers. During the course of their undergraduate study, it is vital that ELT students develop the ability to notice their own errors and repair them. Thus, the development of noticing the gap (skills) must be a central goal in undergraduate ELT education programs in Chile.

However, noticing the gap is a kind of metacognitive awareness that not all learners develop automatically. Therefore, explicit instruction and education are required (Lynch, 2001, 2007; Thornbury, 1997). Several methodologies have been recommended for the development of greater metalinguistic awareness, self-evaluation, and self-monitoring of oral production. Among them, self-transcribing has been proposed as a potential solution to the problem of fossilized errors (Lynch, 2001, 2007). Transcribing and editing oral discourse is a form of linguistic output reprocessing which is done collaboratively. In pairs, students record and transcribe their oral production from an oral task carried out during their language lesson. Still in pairs, they discuss and edit the text they have produced. This edited transcript is handed over to the teacher, who further corrects and reformulates it. Finally, the teacher discusses all the changes with the learners. There is evidence that this method of processing oral output may contribute to interlanguage development and defossilization, resulting in long-term gains in terms of grammatical accuracy (Boettinger, Park, $\mathcal{E}$ Timmis, 2010; Lynch, 2001, 2007; Mennim, 2003, 2012).

My interest in investigating methods and activities which allegedley promote noticing is partly motivated by theoretical concerns, but also by practical, pedagogic concerns. To the best of my knowledge, little research on speaking is and has been conducted in Chile (See note 2), and this study would be pioneering in its focus on the Chilean learner of English. Given the current national debates in Chile about the appropriateness of initial teacher education programs and Chileans' low level of competence to communicate in English as a lingua franca, this research project is both timely and important. Chilean trainee teachers must be competent, confident, and autonomous speakers of English themselves before they can become good language models and guides for their students. It is of utmost importance that the teachers' oral production reach proficiency within the rules of the target language, as their own oral production becomes their students' linguistic input. In fact, in many cases, Chilean ESL teachers are the main (or even the sole) input provider for spoken language.

As the objective of this study was to explore the feasibility and effectiveness of the recording and self-transcription task, the specific objectives were:

(1) To identify the type of English errors a group of students at the intermediate level make when taking a placement test (FCE)

(2) To determine if there is evidence of learners' self-correction

(3) To establish how many of these mistakes the students notice in a self-transcribing task

(4) To examine the perceptions of the learners regarding this new activity: Do they find it useful? How long does it take the participants to produce a typed transcript of three minutes of speech?

(5) To determine the utility and feasibility of this approach from the point of view of the teacher: (How) can it be effectively integrated as a routine classroom activity?

The rest of the paper is structured as follows. In section two, we briefly review the key concepts of this study. The next section will present a summary of 
the data used. Section four will present the findings of the study, ordered according to the five research questions that we had set. In the last section, we draw preliminary conclusions of the study as well as some pedagogical implications and suggestions for future research.

\section{Literature review}

Interlanguage is a central concept in the field of SLA. This term was coined by Selinker (1972) and it refers to the developing knowledge system that a learner has of a second language (L2). This system is independent from both the learner's native language (L1) and the target language (L2). Although interlanguages are systematic, they are also dynamic. They are expected to gradually approximate the target language as learners receive more linguistic input and check their hypotheses about the L2. However, in many cases interlanguage development stops before the language learner can reach ultimate attainment in all aspects of the target language. For example, a learner can achieve a high level of grammatical accuracy or great fluency, but his/her pronunciation fails to resemble that of native speakers of the target language. This process is yet another example of fossilization (Selinker, 1972). According to the literature, this persistent lack of progress is observed in $40-85 \%$ of interlanguages, regardless of how long the language learners have been exposed to the target language or have received instruction (Birdsong, 2004; Montrul E Slabakova, 2003, White, 2003). Fossilization (Selinker, 1972) or cessation of learning is a well documented phenomenon in the field of SLA (Han E Odlin, 2006).

Grammatical errors are one of the manifestations of fossilization. But exactly what constitutes a grammatical error has remained a controversial topic since the 1970s (Andersen, 2011; Chunhong E Griffiths, 2012; Shahin, 2011; Thewissen, 2009). In fact, to this day no single agreed upon definition of error exists, or how precisely it is related to 'correct' or 'native' language (Chunhong \& Griffiths, 2012). In this study, I've chosen to broadly define error as "an unsuccesful bit of language" (James, 1998). This definition of error sensu lato encompasses "variously termed mistakes, slips or lapsi calami, namely deviances which the writer would have been able to correct himself if someone had drawn his attention to them" (Andersen, 2011, p. 23). As a complement, I also follow Lennon (1991), who defines an error as "a linguistic form or combination of forms which in the same context and under similar conditions of production would, in all likelihood, not be produced by the speaker's native speaker counterparts" (Lennon, 1991, p. 182). It is worth noting that it would be inappropriate to compare spontaneous speech to a carefully rehearsed public speech or an informal e-mail to a Nobel Prize winning novelist. This is an important consideration as the language produced by both NSs and NNSs is context-dependent and speaker-dependent and does not conform to a single standard (Andersen, 2011).

At the risk of vastly oversimplifying the complexity of this area of research, it is possible to identify two hypotheses which attempt to explain interlanguage development, namely, the Input Hypothesis (Krashen, 1985) and the Output Hypothesis (Swain, 1985, 1993; Swain E Lapkin, 1995). The hypothesis proposed by Krashen (1985) argues that learners acquire the target language subconsciously through exposure to comprehensible input, i.e. linguistic input they are able to understand. However, some linguists contest the claim that input alone is sufficient for learners to achieve native-like proficiency in a second language (Payne \& Whitney, 2002). For example, some studies which have investigated the effect of immersion programs have found that trainees have not made significant grammatical gains after a six-month stay in an English-speaking country (DeKeyser, 2007).

The Output Hypothesis was proposed by Swain (Swain, 1985, 1993; Swain E Lapkin, 1995) to complement Krashen's input hypothesis. Swain suggests that output, i.e. the learner's oral production in the target language, plays a fundamental role in the development of oral proficiency. A central notion to this hypothesis is the concept of comprehensible output or "pushed" output. In other words, when speaking in the L2, learners are "pushed" to make themselves understood and thus they are more likely to use more sophisticated linguistic forms. This means that sometimes they may have to reword a 
previous utterance or use linguistic forms they had never used before. Thus, the Output Hypothesis holds that output can trigger certain cognitive processes that facilitate the acquisition of a second language. These include "noticing the gap," which is defined as learners' awareness of the disparity between their own oral production and the language produced by native speakers or more advanced learners. Swain $(1985,1993)$ claims that this awareness of the gaps in their linguistic knowledge enables learners to detect their own errors, reevaluate their assumptions about the target language, and edit their utterances. Errors may be identified by relying on two different sources. Firstly, there is external feedback, which is provided by a third party. This may consist of open repair by an instructor or native speaker, requests for clarification or confirmation by the learner to the interlocutor, or modelling provided by a more advanced speaker. Secondly, there is internal feedback, also known as monitoring (Krashen, 1982), which involves the learner's self-reflection and self-evaluation of the speech they have previously delivered.

Self-corrections or self-repairs are taken as a measure of accuracy since they denote both attention to form and an attempt at being accurate (Gass \& Selinker, 2008; Gilabert, 2007; Kormos, 1999; Smith, 2008). Self-correction has been defined as "self-initiated, self-repair, [which] occurs when a learner corrects his or her own utterance without being prompted to do so by another person" (Foster E Ohta, 2005, p. 420). Thus, they are also considered as positive evidence that learners' noticing skills are well developed. Language learners' ability to monitor and modify their own output is desirable, since the literature indicates that complexity, accuracy, and fluency (also known as CAF) are measures of a good command of a second language (Larsen-Freeman, 2009). Accuracy refers to the degree of conformity to the morphosyntactic, phonological, and lexical rules of the target language (Pallotti, 2009).

Various techniques have been claimed to promote metacognitive awareness in the context of ESL instruction: corrective feedback from the teacher (Russell, 2009), self-evaluation through reformulation and reconstruction tasks (Thornbury,
1997), retrospective verbal reports (Egi, 2004), proof-listening (Lynch, 2001), the practice-exposureinstruction-practice sequence in conversational tasks in which learners witness proficient speakers performing the same task ([Thornbury \& Slade, 2006) and, finally, transcribing and collaborative editing of oral texts produced by learners (Foster E Skehan, 1999; Kindt, 2000; Lynch, 2001, 2007; Stillwell et al., 2010).

Self-transcribing is a student-initiated form of an oral output reprocessing task. In this task, students are "responsible for transcribing their L2 speech verbatim and then for improving it in ways that occur to them once they see their words in black and white" (Lynch, 2007, p. 312). In pairs, students discuss and edit the oral text they have produced. The edited transcript is then submitted to the teacher, who further corrects and reformulates the text. Finally, the teacher discusses all the changes with learners (Lynch, 2001, 2007).

This activity has been claimed to present a number of advantages ( Boettinger, Park, $\mathcal{E}$ Timmis 2010; Burns \& Joyce, 1997; Lynch, 2001, 2007; Mennim, 2003, 2012; Stillwell et al., 2010; Thornbury \& Slade, 2006; Willis \& Willis, 1996). First, in terms of cognitive economy, this selftranscribing procedure optimizes the allocation of attentional resources in an offline task. Normally, during the course of a communicative task in real time, an online task, students are more focused on the content of the conversation, i.e. in the negotiation of meaning. Post-task transcribing allows students to revisit their output and focus their attention on linguistic forms (grammatical, lexical, phonological, etc.). Second, in terms of language anxiety, post correction may be less inhibitory for students than online correction. The fact that the communicative task has been carried out with a certain level of success takes some of the pressure off learners. Third, having the transcript of a conversation allows for selective attention to different features of the data, such as the use of discourse markers, intonation patterns, evaluative language, etc. Thus, data can be revisited many times and on each occasion students may be asked to shift their attention to a different aspect. Fourth, metalinguistic and metacognitve awareness stems 
from two sources, internal and external, through selfcorrection and other-feedback (the peer's and the teacher's).

It is noteworthy that intermediate level ESL students are more likely to benefit more from consciousness raising methodologies like transcribing for a number of reasons (Kormos, 1999; Payne E Whitney, 2002; Philp, 2003; Richards, 2008; Smith, 2008). First, unlike beginners, intermediate learners possess a deeper linguistic knowledge, which is essential for metacognitive and metalinguistic awareness. Second, for intermediate learners, some conceptualization and formulation processes involved in the planning stage of oral production have become automatic. This liberates attentional resources, which can be allocated to self-monitoring and repair at the formulation stage. Third, intermediate learners tend to reach a learning plateau (Richards, 2008; Xu, 2009), namely, intermediate learners are more likely to stop making progress than basic-level language learners. Progress at the intermediate level is slower and it requires more effort by the learner, so there is a higher likelihood that learners will lose motivation to acquire error-free English. This is the reason why ELT learners need help to move beyond the intermediate plateau in order to reach an advanced level of language proficiency.

\section{Methodology}

As mentioned above, in this study I set out to explore the feasibility and effectiveness of the recording and self-transcription task (Lynch, 2001, 2007; Mennim, 2003, 2012) as a route to noticing the gap and defossilization. Although I use some quantitative measures (mean, standard deviation), the research is essentially qualitative: (1) it is a multiple case study (20 students enrolled in an ELT education program at P(CV), so the results are not generalizable, and (2) it explores the participants' perceptions as to the impact of self-transcribing tasks. In the sense that the present study is the first phase of a planned future intervention as a response to a specific problem (fossilization), and the evaluation of that intervention, this study could also be said to fall under an action research paradigm (Boettinger, Park, E Timmis, 2010).

\section{Research questions}

In line with the aforementioned objectives of this study, the research questions to which this article seeks to provide answers are as follows:

1. What kind of English errors does a group of students at the intermediate level produce when taking the speaking section of a placement test (FCE)?

2. Is there evidence of self-correction?

3. In a self-transcribing task, how much do they notice, by way of English errors? In which areas (grammar, vocabulary, sounds, etc.)?

4. What are the perceptions of the learners regarding this task: Do they find it useful? Is it perceived as time-consuming?

5. What are the feasibility and potential benefits of a transcript-based task? (How) Can it be effectively integrated as a routine classroom activity?

\section{Participants}

I worked with "intact classes" (Mackey E Gass, 2005; Lynch, 2007) not specifically created for research purposes. Here I follow Mackey and Gass (2005), who posit that, although intact classes are not typical of experimental research, they have the advantage of enhancing the face validity of classroom research on the effects of a particular instructional method, which is precisely the nature of the proposed research. According to these authors, "an existing classroom may be the most ecologically sound setting for research" (Mackey \& Gass, 2005, p. 143).

The twenty participants in this study $(\mathrm{F}=$ 13, $M=7$ ) are the twenty students of the ELT program at PUCV who were enrolled in one of the subjects I taught during the first semester of our 2013 academic year, namely, English 5. They are all Chilean and native speakers of Spanish. All participants were consenting adults whose ages ranged from 20 to 23 (mean age $=21$ ). All of them are aiming to become EFL teachers.

All of them are at an intermediate level of language proficiency, which was confirmed after administering a placement test (FCE) at the 
beginning of the semester used as a diagnostic test. Our ELT program includes eight semesters of English, so by the time students enroll in English 5 , they are expected to demonstrate ability at Level 2 and Council of Europe Level B1 or, ideally, B2. However, our students do not receive a grade on this diagnostic test. They are informed, however, of their scores in the different sections so they can monitor their progress in the different skills throughout the semester. Thus, this assessment procedure can be characterized as low-stakes.

\section{Procedure}

The participants received via email the audio file (in mp3 format) of their performance in the speaking section of the diagnostic test (FCE format). The speaking section of the FCE exam has four parts and is conducted face-to-face, with two candidates (students) and one examiner (the teacher). Candidates are expected to be able to participate in discussions, express opinions, exchange ideas, and reach decisions through negotiation. The speaking test assesses the candidate's ability to interact in conversational English in a range of contexts. On average, the students took 15 minutes to complete this section.

The twenty participants were asked to (1) transcribe a three-minute segment of their speech, (2) highlight all the errors they identified (3) code them (e.g. grammatical, lexical, phonological, etc.) by highlighting them with different colors, and (4) send by email the annotated transcript to the instructor. Students were asked to categorize their errors as an attempt to help them identify one area of improvement in which they could focus on during the remainder of the semester.

Drawing on Dörnyei's (2003) theory of questionnaire design and processing, I developed a survey (14 questions) that was posted online (GoogleForm) and emailed to the students. The questionnaire set out to identify the students' perceptions of the potential benefits of the selftranscription task. The study data consist of 19 annotated transcripts (one of the participants did not annotate his text) produced by the participants and 20 questionnaire responses.

The transcripts were collated by the researcher with the audio recordings of the diagnostic test, in order to ensure that the transcript was true to the oral text produced by the participants. They were further coded by the researcher, who identified additional mistakes which had gone unnoticed by the students.

\section{Results and discussion}

In this section, the results of the study are presented (ordered by research question) and discussed in light of what has been reported in the literature.

\section{Types of mistakes}

Students managed to categorize their errors efficiently. In other words, they were able to correctly sort out the errors they managed to identify. The results, as shown in Table 1, indicate that $49 \%$ of the errors the students made were grammatical (predominantly verb tenses), 35\% were lexical, and only $16 \%$ were related to pronunciation. Interestingly, the participants did not make any errors at the suprasegmental level, as expected. This finding is in agreement with Lynch's (2001) findings which showed that students made more grammatical errors than any other type. Regrettably, Mennim's (2003) study does not specify the percentage of corrections to grammar, pronunciation and content.

\section{Do students self-repair?}

Another conspicuous finding is the low rate of self-repairs. As shown in Table 1, only 12 out of the 20 participants initiated self-corrections (standard deviation $=0$ ) during their speaking, and only one student (EJ) did it more than twice. This might also be attributable to the perception of the stakes of the diagnostic test: Their linguistic performance is not being graded, so students don't feel the pressure to self-monitor as much as they would in 
Developing the metacognitive skill of noticing the gap through self-transcribing

Table 1. Results obtained from the analysis of the transcriptions

\begin{tabular}{|c|c|c|c|c|c|c|c|}
\hline Participants & $\begin{array}{c}\text { Errors } \\
\text { identified } \\
\text { by students }\end{array}$ & $\begin{array}{c}\text { Errors } \\
\text { identified } \\
\text { by } \\
\text { instructor }\end{array}$ & $\begin{array}{c}\text { Grammatical } \\
\text { errors }\end{array}$ & $\begin{array}{l}\text { Lexical } \\
\text { errors }\end{array}$ & $\begin{array}{l}\text { Phonological } \\
\text { errors }\end{array}$ & Self-repairs & $\begin{array}{l}\text { Total } \\
\text { number of } \\
\text { errors }\end{array}$ \\
\hline$A C$ & 5 & 4 & 7 & 2 & 0 & 1 & 9 \\
\hline MAM & 7 & 7 & 7 & 5 & 1 & 1 & 14 \\
\hline $\mathrm{JR}$ & 2 & 11 & 3 & 3 & 7 & 0 & 13 \\
\hline CB & 1 & 3 & 2 & 2 & 0 & 1 & 4 \\
\hline MFM & 0 & 6 & 1 & 4 & 1 & 1 & 6 \\
\hline $\mathrm{CP}$ & 2 & 11 & 7 & 3 & 1 & 0 & 13 \\
\hline RJ & 4 & 2 & 4 & 2 & 0 & 0 & 6 \\
\hline $\mathrm{CC}$ & 0 & 7 & 6 & 1 & 0 & 2 & 7 \\
\hline $\mathrm{FV}$ & 5 & 6 & 7 & 3 & 1 & 0 & 11 \\
\hline OM & 2 & 5 & 2 & 2 & 1 & 1 & 7 \\
\hline $\mathrm{CL}$ & 2 & 6 & 5 & 1 & 2 & 1 & 8 \\
\hline DR & - & - & 6 & 6 & 2 & 1 & 14 \\
\hline EJ & 6 & 9 & 7 & 7 & 1 & 3 & 15 \\
\hline $\mathrm{CR}$ & 1 & 9 & 4 & 2 & 4 & 0 & 10 \\
\hline EG & 0 & 4 & 2 & 1 & 1 & 1 & 4 \\
\hline MN & 3 & 9 & 7 & 2 & 3 & 0 & 12 \\
\hline $\mathrm{EF}$ & 4 & 7 & 8 & 2 & 1 & 0 & 11 \\
\hline SC & 1 & 13 & 4 & 8 & 2 & 1 & 14 \\
\hline $\mathrm{NR}$ & 3 & 2 & 1 & 4 & 0 & 1 & 5 \\
\hline NG & 0 & 6 & 0 & 5 & 1 & 0 & 6 \\
\hline Total & 50 & 133 & 90 & 65 & 29 & 15 & 189 \\
\hline Mean & 2.5 & 6.68 & $49 \%$ & $35 \%$ & $16 \%$ & - & 9.2 \\
\hline $\begin{array}{l}\text { Standard } \\
\text { deviation }\end{array}$ & 2 & - & - & - & - & 0 & - \\
\hline
\end{tabular}

the context of a test. In fact, one of the students reported that the reason he wasn't nervous during the test was "because I knew it wasn't officially graded." Although a future study should seek out corroborating evidence for the claim that students self-repair more often in this type of context.

Another possible explanation for the low occurrence of self-correction could be language anxiety: A majority of participants $(65 \%)$ in the survey indicated they were nervous while taking the oral test. Among the reasons cited were (1) the fact that they didn't know the instructor ("I was a little because, first of all, I've never had a class with
Miss Salas before and I didn't know her or her ways of evaluation"), (2) that they usually get nervous when speaking in front of a teacher ("Because I tend to be nervous when I have to speak in English in front of a teacher. It's unconscious"), (3) that speaking English in general is stressful ("Because I'm not very confident with myself when I'm speaking in English"), and (4) they were being recorded ("I tend to get really nervous when I'm being recorded"). As there is some evidence that debilitating anxiety may have a negative effect on the speaking skill (Hewitt $\mathcal{E}$ Stephenson, 2012), there might be a link between self-repair and debilitating anxiety. 


\section{How much did the students notice?}

In transcribing their own speech, on average the students noticed 50 errors out of 184 (standard deviation $=2$ ), which roughly amount to $25 \%$ of their mistakes. Taken as an average of 2.5 language forms per student over three minutes of talk, this is a lower rate than the students in Lynch's (2001) study, when each student noticed around 14 such points in just two minutes of speech, and Mennim's (2003) study, when students found 16 over five minutes of speaking time.

This is a striking result, considering the fact that students reported they had listened to the recording several times (the mode was three times). This result may be explained by a number of different factors. While the participants of Lynch's and Mennim's studies were able to work on several improved versions of the transcript over a span of several weeks, even months, my students carried out a onetime task which did not involve a reformulation of the transcript. Another explanation for this result may be the lack of pairwork. Unlike Lynch's and Mennim's participants, mine worked on their own, which means that they didn't count on other-correction. In Lynch (2001), a full $50 \%$ of corrected errors were identified by a peer, so it is probably safe to assume that if the participants of the current study had relied on other-correction, the tally in this study might have doubled. The reason for not adopting the original collaborative editing framework was classroom management. This study reports the results of a first implementation of the self-transcription activity in which students worked on their own outside the classroom. During the rest of semester, students were meant to edit the transcripts in pairs and in class in order to benefit from peer-interaction and co-construction of knowledge.

A third possible explanation for this might be that the participants in the other studies (Lynch, 2001, 2007; Mennim, 2003, 2012) were working towards an end, namely, reformulation, and transcribing was perceived as a high-stakes activity: as part of a pre-sessional course at the University of Edinburgh (Lynch, 2001), a 13-week EAP programme in 1999 preparing international students for entry into British universities (Lynch, 2007), or a graded oral presentation (Mennim, 2003). My students, in contrast, may have assessed this as a low-stakes task, since it was not graded and I did not offer to provide a corrected version of the transcript, which may have resulted in a lack of motivation to complete the task satisfactorily.

One unanticipated finding was that 11 of the 20 students (55\%) respondents believe that repetitions, false starts, use of fillers, pauses, etc. are "errors." And consequently, they highlighted in their transcript these perceived "errors" as such. It is interesting to note that a previous study (Stillwell et al., 2010) reports similar findings.

According to the literature (Carter $\&$ McCarthy, 2006; Mumford, 2009; Timmis, 2012), however, all of the aforementioned phenomena fall within the scope of normal disfluency, that is, common disorders in the flow of speech, which are typical of normal speakers (unlike stuttering, for example), especially in situations where the speaker is stressed or anxious (e.g. in the context of testing). Pause fillers ("uh/er," "um/erm"), vagueness expressions ("sort of." "I mean") and repetitions are considered production strategies, that is, tricks speakers use to "compensate for the attentional demands involved in speech production" (Thornbury, 2005, p. 7). In the current study, the most commonly used fillers are: "yeah," "I do not know," "well," "uh," "and," "so," and "like." A pattern that emerged from the data was that each student has one or more favorite fillers which they tend to use as a linguistic crutch. Considering that repetitions and false starts are not actual errors, they are not included in the column "Errors identified by students" in Table 1 .

According to Tanskanen (2006), repetition is the pattern of cohesion with the highest frequency in face-to-face conversations. Tannen (1989) and Norrick (1987) maintain that repetition has a special function in conversation and that it is specifically used for interactive purposes. It may also allow speakers to gain time while they think about what to say next (Boettinger, Park, \& Timmis, 2010). In this study, the data show that the repetition of lexical items serves several purposes: to manage the topic, to gain time, and to emphasize an idea. Thus, I have to agree with Stillwell et al. (2010) on the importance of discussing with students the differences between 
spoken and written grammars, and the validity of some features of interactive speaking, such as false starts, fillers, and redundancies.

\section{The students' attitudes to the transcribing task}

The findings of the current study are consistent with those of Lynch (2007), Stillwell et al. (2010), and Mennim (2012) who report a favourable assessment of the exercise by the participants in their studies. All 20 respondents felt that the selftranscribing task helped them gain both awareness of some problems in their oral production and insight into their language development. However, it is important to bear in mind the possible response bias in these overwhelmingly positive responses, especially considering how much effort the participants actually put into performing the task.

Despite the positive appraisal, and according to their reponses to one of the survey questions, only nine students chose the segment to be transcribed after careful analysis of which section of their speech presented more problems in terms of accuracy and fluency. The rest picked the segment randomly, for example, the first three minutes of their speech, regardless of the quality of their oral production in that section. In a future application of this procedure, I will be sure to lay this out as one of the guidelines for the self-transcribing task.

Turning now to the question of how time consuming the self-transcribing task would be, reports in the literature suggest that the amount of time which is required to produce an accurate transcript ranges from 4 to 10 minutes per each minute of recorded speech (Lynch, 2001; Mackey $\varepsilon$ Gass, 2005). That would mean that for a threeminute segment, students should take between 12 30 minutes. However, the results of the present study suggest this may be a conservative estimate. Of the 20 students who completed the questionnaire, just over half (11) fall within this time range. Even though the mode was 15 minutes (seven participants), and four other respondents indicated that they needed 20 minutes to transcribe their three minutes of talk, six students required much longer (three an hour, two an hour and a half, and one student more than two hours). Three of the respondents could not recall exactly how long they had taken to complete the task.

\section{Feasibility and potential benefits of a transcript-based task}

Returning to the question posed at the beginning of this study (namely, can this task be effectively integrated as a routine classroom activity?), it is now possible to state that, despite the positive assessment of this task by the participants of the study, there are several important caveats concerning its successful implementation. First, in order to enhance the effectiveness of this activity, the guidelines laid out for the task should be more specific (e.g. selecting the worst part of their speech for transcribing) to facilitate noticing. Prior to the implementation of the activity, the instructor should explain what an error is and stress the validity of some features of spoken grammars, such as false starts, fillers, and repetition.

Second, in order to increase the perceived value of such an activity, students should be working towards a clear goal, for example, preparing a graded oral presentation. If students perceive this as a high-stakes task, they might be motivated to invest more effort in writing and annotating the transcript.

Third, in terms of classroom implementation, there are at least two important considerations: class size and equipment. Regarding class size, and based on what the literature reports and my own experience implementing this activity, a small-sized class seems the most appropriate setting. It took me on average 20 minutes to collate each of the 20 transcripts with the audio recording and add my own annotations, which fell within my allowance at my institute in terms of preparation time. Considering the Chilean context, however, in which most college professors are not paid for lesson planning time, this task could impose an excessive burden on the teacher as it would have to be done on their own time.

Now, turning to electronic equipment concerns, I own two digital recorders, so I can record only two pairs or groups of students at a time. However, most 
of my students own very sophisticated smartphones, which allow you to record audio and even make videos. So in a future application of this activity, I would ask my students to record themselves and then send me the audio file by e-mail, which is feasible in the context of tertiary education in Chile.

\section{Conclusions}

The purpose of the current study was to explore the feasibility and potential benefits of a transcriptbased task based on learners' spoken L2 output, especially in light of the encouraging results which have been reported in the literature (Boettinger, Park E Timmis 2010; Burns \& Joyce, 1997; Lynch, 2001, 2007; Mennim, 2003, 2012; Stillwell et al., 2010; Thornbury \& Slade, 2006; Willis \& Willis, 1996). There is some evidence that this technique promotes the metacognitive skill of noticing the gap, a crucial factor in achieving a high level of language proficiency. As mentioned above, one of the main concerns in ELT education programs in Chile is precisely the quality of the future teachers' oral production as, in many cases, they may be the sole providers of linguistic input in the EFL classroom.

One of the more significant findings to emerge from this study is that, in annotating their own transcripts, students only noticed 1 out of 4 errors in a transcript of three minutes' talk. This finding was unexpected and suggests that self-transcribing must be motivated as it places high cognitive demands on the learner. Despite the positive remarks made by the students, few of them invested much effort in writing and annotating the transcript as attested by the amount of time it took them to complete both tasks (the mode was 15 minutes). These rather disappointing findings may be explained by reference to other studies which have been reviewed in this article. While in my study, self-transcribing was conducted in a single intervention and as an exploratory activity at the start of the semester, participants in other studies have been assigned this type of task several times over a period of time (a whole semester, in some cases) and with a clear goal: to prepare for high-stakes spoken tasks.

A number of caveats need to be noted regarding the present study. The most important limitation lies in the fact that this was an exploratory study and as such the findings are preliminary. In order to corroborate the claims made about the defossilizing effects of self-transcribing, a proper replication of Lynch's (2001) and Mennim's (2003) studies should be conducted with a control group and an experiment group, which is what my next study sets out to do. Another reservation I must acknowledge about the research methodology employed here is that small scale action research is by definition limited in its generalisability. Thirdly, the study did not include a follow-up on the second application of this task. Regrettably, this was hindered by the 3-month strike students of our program participated in as part of the student movement protests in Chile. A follow-up has been scheduled for next year (2014 academic year) to enable more robust findings to emerge.

As stated above, the development of metalinguistic awareness can increase learner autonomy, facilitate the progress of L2 learning, and prevent fossilization. Thus, more research is required to determine the efficacy of self-transcribing tasks, as well as other techniques, in the Chilean context. This is a particularly critical issue for ELT education programs in Chile as the Ministry of Education is allocating more funds for improving the quality of graduates from these programs, for example, through more study-a-semester-abroad scholarships, but not all of our students have access to them. And even when they do, there is no guarantee of improved oral production in the L2. We need more research into what we can do in our classrooms to foster nativelike L2 ultimate attainment in speaking.

This research has brought up many questions in need of further investigation: How can the effectiveness of this activity be measured? How can gains in metalinguistic awareness be operationalized? Through a higher rate of self-repairs? A future longitudinal study investigating long-term gains of the self-transcribing task would be very interesting.

\section{Notes}

(1) According to a study conducted in 2008 by the Faculty of Economics and Administrative Sciences, University of Chile, and a report by the Inter-American 
Development Bank in 2011, only 2 percent of the Chilean population (approximately 265,000) speak English fluently.

(2) Admittedly, there are a growing number of studies in applied linguistics conducted by Chilean researchers in different areas related to TESOL: blended learning (Bañados, 2013), writing (Pichihueche, 2012), EAP reading (lbáñez, 2008), listening (Vásquez \& Vivanco, 2015), help options in listening materials in CALL (Cárdenas-Claros $\varepsilon$ Gruba, 2014; Cárdenas-Claros \& Oyanedel, 2015), multimodal learning and its implications for TEFL (Farías, Obilinovic, \& Orrego, 2013), oral assessment (Baitman \& Véliz, 2013), teaching models of English pronunciation (Véliz, 2011), student beliefs in language teaching education (Ochoa et al., 2014), primary school students' beliefs on the learning of English (Díaz \& Morales, 2015), drama as a teaching method (Lizasoain, Ortiz de Zárate, Walper, \& Yilorm, 2012), ICTs in rural education (Lizasoain $\mathcal{E}$ Becchi, 2014), and automatic intonation assessment (Arias, Becerra, \& Vivanco, 2010). However, to the best of my knowledge, in the last decade little research on speaking has been conducted in Chile. Two exceptions are Cárcamo (2014) and Oyanedel (2015). The focus of Oyanedel's (2015) study is a rehearsed spoken genre, the academic oral presentation, while Cárcamo's (2014) study focuses on task repetition and feedback to improve speaking. Thus, the present study would be pioneering in its focus on the Chilean learner of English.

\section{References}

Andersen, E. (2011). Grammatical error prediction. Technical Report, University of Cambridge, Computer Laboratory, (794), 1-163.

Arias, J. P., Becerra, N., E Vivanco, H. (2010). Automatic intonation assessment for computer aided language learning. Speech Communication, 52, 254-267.

Baitman, B., \& Véliz, M. (2013). A comparison of oral evaluation ratings by native English speaker teachers and non-native English speaker teachers. Literatura y Lingüística, 27, 171-200.

Bañados, E. (2013). A blended-learning pedagogical model for teaching and learning EFL successfully through an online interactive multimedia environment. CALICO Journal, 23(3), 533-550.
Birdsong, D. (2004). Second language acquisition and ultimate attainment. In A. Davis \& C. Elder (Eds.), The Handbook of applied linguistics (pp. 82-104). Malden, MA: Blackwell.

Boettinger, F., Park, J., E Timmis, I. (2010). Self-directed noticing for defossilization: Three Case Studies. International Journal of English Studies, 10(1), 43-64.

Burns, A., E Joyce, H. (1997). Focus on Speaking. Sydney: NCELTR.

Cárcamo, B. (2014). Action Research: Improving performance in interaction tasks by implementing effective feedback strategies and task repetition. Tesis para optar al grado de Magíster en Lingüística Aplicada, Inglés Lengua Extranjera (ILE), Pontificia Universidad Católica de Chile.

Cárdenas-Claros, M. S., E Gruba, P. A. (2014). Listeners' interactions with help options in CALL. Computer Assisted Language Learning, 27(3), 228-245.

Cárdenas-Claros, M., \& Oyanedel, M. (2015). Teachers' implicit theories and use of ICTs in the language classroom. Technology, Pedagogy and Education, (ahead-of-print), 1-19.

Carter, R., \& McCarthy, M. (2006). Cambridge grammar of English. Cambridge: Cambridge University Press.

Chunhong, Z., \& Griffiths, C. (2012). Quantitative and qualitative perspectives on individual differences in error correction preferences. In M. Pawlak (Ed.), New perspectives on individual differences in language learning and teaching, second language learning and teaching (pp. 305-317). Berlin: Springer-Verlag.

DeKeyser, R. M. (2007). Study abroad as foreign language practice. In R. M. DeKeyser (Ed.), Practice in a second language: Perspectives from applied linguistics and cognitive psychology (pp.208-226). New York: Cambridge University Press.

Díaz Larenas, C., \& Morales Campos, H. (2015). Creencias de estudiantes de primaria sobre el aprendizaje del inglés en un establecimiento educacional chileno. Actualidades Investigativas en Educación, 15(1), 1-20.

Dörnyei, Z. (2003). Questionnaires in second language research: Construction, administration and processing. Mahwah, New Jersey: Lawrence Erlbaum.

Egi, T. (2004). Verbal reports, noticing, and SLA research. Language Awareness, 13(4), 243-264.

Ellis, R. (1997). Second language acquisition. Oxford: Oxford University Press.

Farías, M. A., Obilinovic, K. A., \& Orrego, R. C. (2013). El principio y efecto de redundancia en la retención y transferencia de expresiones idiomáticas en inglés como lengua extranjera. Íkala, 18(1), 9-17. 
Foster, P., \& Skehan, P. (1999). The influence of source of planning and focus of planning on task-based performance. Language Teaching Research, 3(3), 215-247.

Foster, P., \& Ohta, A. S. (2005). Negotiation for meaning and peer assistance in second language classrooms. Applied Linguistics, 26, 402-430.

Gass, S. M., E Selinker, L. (2008). Second language acquisition: An introductory course. London: Taylor E Francis

Gilabert, R. (2007). Effects of manipulating task complexity on self-repairs during L2 oral production. International Review of Applied Linguistics in Language Teaching, 45(3), 215-240.

Han, Z., \& Odlin, T. (Eds.) (2006). Studies of fossilization in second language acquisition. Clevedon, England: Multilingual Matters.

Hewitt, E., E Stephenson, J. (2012). Foreign language anxiety and oral exam performance: A replication of Phillips's MLJ study. The Modern Language Journal, 96(2), 170-189.

Ibáñez, R. (2008). Comprensión de textos académicos escritos en inglés: Relación entre nivel de logro y variables involucradas. Revista Signos, 41(67), 203229.

James, C. (1998). Errors in language learning and use: Exploring error analysis. London: Longman.

Kindt, D. (2000). Don't forget your SOCCS! Developing communication skills with students' own conversation cards. Nagoya, Japan: Department of British and American Studies, Nanzan University.

Kormos, J. (1999). Monitoring and self-repair in L2. Language Learning 49(2), 303-342.

Krashen, S. (1982). Principles and practice in second language acquisition. London: Pergamon.

Krashen, S. (1985). The input hypothesis: Issues and implications. Beverly Hills, CA: Laredo.

Larsen-Freeman, D. (2009). Adjusting expectations: The study of complexity, accuracy and fluency in second language acquisition. Applied Linguistics, 30(4), 579-589.

Lennon, P. (1991). Error: Some problems of definition, identification, and distinction. Applied Linguistics, 12(2), 180-196.

Lightbown, P. M., \& Spada, N. (2006). How languages are learned (Third edition). Oxford, Inglaterra: Oxford University Press.

Lizasoain, A., Ortiz de Zárate, A., Walper, K., \& Yilorm, Y. (2012). Descriptive and exploratory study of an introductory workshop to drama techniques for teaching/learning a foreign language. Estudios Pedagógicos, 38(2), 157-167.

Lizasoain, A., E Becchi, C. (2014). Evaluation of a rural self-learning English program in Chile. Enjoy Teaching Journal, 2(2), 4-18.

Llurda, E. (2005). Non-native language teachers: Perceptions, challenges and contributions to the profession. New York: Springer.

Lynch, T. (2001). Seeing what they meant: Transcribing as a route to noticing. ELT Journal, 55(2), 124-132.

Lynch, T. (2007). Learning from the transcripts of an oral communications task. ELT Journal, 61(4), 311-320.

Mackey, A., \& Gass, S. (2005). Second language research: Methodology $\mathcal{E}$ design. Mahwah, New Jersey: Lawrence Erlbaum.

Mennim, P. (2003). Rehearsed oral L2 output and reactive focus on form. ELT Journal, 57(2), 130-138.

Mennim, P. (2012). Learner negotiation of L2 form in transcription exercises. ELT Journal, 66(1), 52-61.

Mitchell, R., \& Myles, F. (2004). Second language learning theories. New York: Hodder Arnold.

Montrul, S., \& Slabakova, R. (2003). Competence, similarities between native and near-native speakers: An investigation of the preterite-imperfect contrast in Spanish. Studies in Second Language Acquisition, 25(3), 351-398.

Mumford, S. (2009). An analysis of spoken grammar: The case for production. ELT Journal, 63(2), 137-144.

Norrick, N. R. (1987). Functions of repetition in conversation. Text, 7, 245-264.

Ochoa, T. T., Larenas, C. D., Hernández, P. A., Lara, M. Q., \& Leiva, L. R. (2014). Creencias de estudiantes de pedagogía sobre la enseñanza del inglés. Revista Folios, 39, 77-87.

Oyanedel, M. (2015). La presentación oral académica online en una segunda lengua: Una aproximación a la categorización de los tipos de conocimientos metacognitivos en su etapa de elaboración. Tesis para optar al grado de Doctor en Lingüística, Pontificia Universidad Católica de Valparaíso.

Pallotti, G. (2009). CAF: Defining, refining and differentiating constructs. Applied Linguistics, 30(4), 590-601.

Payne, J. S., \& Whitney, P. J. (2002). Developing L2 oral proficiency through synchronous CMC: Output, working memory, and interlanguage development. CALICO Journal, 20(1), 7-32.

Philp, J. (2003). Constraints on "noticing the gap." Studies in Second Language Acquisition, 25(01), 99-126. 
Pichihueche, R. (2012). The 'argument-is-war' and the dialectical discoursal patterns: Their acquisition and use by TEFL students in written argumentative texts. Lenguas modernas, 40, 79-102.

Richards, J. C. (2008). Moving beyond the plateau: From intermediate to advanced levels in language learning. New York: Cambridge University Press.

Russell, V. (2009). Corrective feedback, over a decade of research since Lyster and Ranta (1997): Where do we stand today? Electronic Journal of Foreign Language Teaching, 6(1), 21-31.

Selinker, L. (1972). Interlanguage. International Review of Applied Linguistics, 10, 209-231.

Shahin, N. (2011). Error treatment in TESOL classrooms. Jordan Journal of Applied Science: Humanities Series, 13(1), 207-226.

Smith, B. (2008). Methodological hurdles in capturing CMC data: The case of the missing self-repair. Language Learning \& Technology, 12(1), 85-103.

Stillwell, C., Curabba, B., Alexander, K., Kidd, A., Kim, E., Stone, P., \& Wyle, C. (2010). Students transcribing tasks: Noticing fluency, accuracy, and complexity. ELT Journal, 64(4), 445-455.

Swain, M. (1985). Communicative competence: Some roles of comprehensible input and comprehensible output in its development. In S. Gass \& C. Madden (Eds.), Input and second language acquisition. Rowley, MA: Newbury House.

Swain, M. (1993). The output hypothesis: Just speaking and writing aren't enough. The Canadian Modern Language Review, 50, 158-164.

Swain, M., E Lapkin, S. (1995). Problems in output and the cognitive processes they generate: A step towards second language learning. Applied Linguistics, 16, 371-391.

Tannen, D. (1989). Talking voices: Repetition, dialogue, and imagery in conversational discourse. Cambridge: Cambridge University Press.
Tanskanen, S. K. (2006). Collaborating towards coherence. Amsterdam: John Benjamins.

Thewissen, J. (2009). Determinants of error status: Reframing the construct of error. In $30^{\text {th }}$ annual conference of the International Computer Archive of Modern and Medieval English (ICAME 30), Lancaster University (pp. 27-31).

Thornbury, S. (1997). Reformulation and reconstruction: Tasks that promote "noticing". ELT Journal, 51(4), 326-335.

Thornbury, S. (2005). How to teach speaking. London: Longman.

Thornbury, S., \& Slade, D. (2006). Conversation: From description to pedagogy. Cambridge: Cambridge University Press.

Timmis, I. (2012). Spoken language research and ELT: Where are we now? ELT Journal Volume, 66(4), 514522.

Vásquez, G., \& Vivanco, H. (2015). Aural perception mistakes made by native listeners of Chilean Spanish in decoding an English spoken text. Lenguas Modernas, 44, 115-131.

Véliz, M. (2011). A critical interrogation of the prevailing teaching model(s) of English pronunciation at teachertraining college level: A Chilean evidence-based study. Literatura y Lingüística, (23), 213-236.

White, L. (2003). Fossilization in steady state L2 grammars: Persistent problems with inflectional morphology. Bilingualism: Language and Cognition, 6(2), 129141.

Willis, D., \& Willis, J. (1996). Consciousness-raising activities in the language classroom in the language classroom. In J. Willis, \& D. Willis (Eds.), Challenge and change in language teaching (pp. 237-259). Oxford: Heinemann.

Xu, Q. (2009). Moving beyond the intermediate EFL learning plateau. Asian Social Science, 5(2), 66-68. 


\section{Appendix 1}

\section{SURVEY ON TRANSCRIBING}

1. Did you have the chance to practice your English over the summer break?

Yes No Why?

2. Are you satisfied with your performance in the speaking diagnostic test?

Yes No Why?

3. Were you nervous during the speaking diagnostic test?

Yes No Why?

4. How did you choose which 3 minutes to transcribe? What did you base your decision on?

5. How long did it take you to transcribe the 3 minutes of speaking time?

6. Did you notice any errors you made while listening to the audio file the first time?

Yes $\quad$ No

7. Did you notice any errors your partner made while listening to the audio file the first time?

Yes $\quad$ No

8. While transcribing did you notice any errors you hadn't realized while just listening to the recording?

Yes No Explain.

9. After highlighting your transcription, what do you think is/are your weakest area(s) in speaking? Tick all that apply.

o Grammatical accuracy

o Phonological accuracy

o Word choice

o Fluency

o Other 
10. After highlighting your transcription and coding your errors, what do you identify as your most recurrent errors? Tick all that apply.

o grammatical errors

o vocabulary errors

o $\quad$ pronunciation errors at the syllable level (vowels and consonants)

o pronunciation errors at the word level (stress)

o phonological errors (at the sentence level: intonation patterns, linking sounds, etc.)

11. Approximately how many times did you listen to the recording?

12. Do you think the task of transcribing helped you to be more aware of your problems in your oral production?

Yes No Why?

13. Did you self-correct during the speaking test?

Yes No

What mistakes did you correct?

14. Are you willing to do the necessary work to defossilize the errors that you identified?

Yes No 